\title{
Regulator of G-Protein Signaling 4
}

National Cancer Institute

\section{Source}

National Cancer Institute. Regulator of G-Protein Signaling 4. NCI Thesaurus. Code C101657.

Regulator of G-protein signaling 4 (205 aa, $\sim 23 \mathrm{kDa}$ ) is encoded by the human RGS4 gene. This protein is involved in the promotion of GT Pase activity. 